\title{
Teknologi Fragmentasi Buatan Karang (Caulastrea furcata dan Cynarina lacrimalis) dalam Upaya Percepatan Pertumbuhan pada Kondisi Terkontrol
}

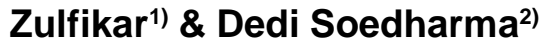 \\ 1) Jurusan Budidaya Perairan Fak. Pertanian Universitas Malikussaleh \\ e-mail: zulsaidy@gmail.com, HP. 085260267773 \\ 2)Jurusan IImu Teknologi Kelautan Fak. Perikanan IPB \\ Diterima 20-08-2007_ Disetujui 17-01-2008
}

\begin{abstract}
The objective of research were analyze water quality condition of water circulation system at laboratory and to measured growth survival rate of Caulastrea furcata and Cynarina lacrimalis which was fragmented at laboratory. Fragmentation treatment of Caulastrea furcata become 1, 2, 3, and 4 polyp that was rearing on circulation system did not give significant impact on height and length growth after 160 days rearing and fragmentation of Cynarina lacrimalis on circulation system give significant impact. Mean of growth length of Caulastrea furcata on treatment $1,2,3$ and 4 polyp in every month after 160 days was $1.64 \mathrm{~mm}, 1.55 \mathrm{~mm}, 1.42 \mathrm{~mm}$, and1.08 mm whereas growth broad was $0.71 \mathrm{~mm}, 0.82 \mathrm{~mm}, 0.51 \mathrm{~mm}, 0.62 \mathrm{~mm}$, and mean of growth length Cynarina lacrimalis for the same treatment in every month was $1.47 \mathrm{~mm}, 0.90 \mathrm{~mm}, 0.62 \mathrm{~mm}, 0.61 \mathrm{~mm}$ whereas growth broad was $1.57 \mathrm{~mm}, 1.16$ $\mathrm{mm}, 0.93 \mathrm{~mm}, 0.89 \mathrm{~mm}$. Fragmentation treatment of Caulastrea furcata become 1 polyp was best length if compare other treatment and Cynarina lacrimalis was treatment became 2 devide.
\end{abstract}

Keywords: Caulastrea furcata, circulationi, Cynarina lacrimalis, fragmentation, water quality

\section{PENDAHULUAN}

Terumbu karang (coral reef) merupakan ekosistem dasar laut yang penghuni utamanya berupa karang batu. Berbagai spesies dan bentuk karang batu ini bersama-sama dengan makhluk hidup lainnya membentuk suatu ekosistem. Secara umum kondisi terumbu karang di Indonesia pada saat ini semakin memburuk sebagai akibat terjadinya degradasi atau kerusakan pada ekosistem terumbu karang. Penyebab terjadinya kerusakan dapat dikelompokkan menjadi dua, yaitu kerusakan yang disebabkan oleh kegiatan manusia seperti penambangan karang, perdagangan karang, pengeboman ikan di daerah terumbu karang dan lain-lain, dan kerusakan yang disebabkan oleh alam yang dapat dibagi lagi yaitu secara fisik seperti adanya badai, perubahan iklim, dan lain-lain dan secara biologis yaitu adanya hewan pemangsa atau predator oleh binatang laut Acanthaster planci (Dahuri 1999).

Terumbu karang Indonesia menempati areal seluas $85.707 \mathrm{~km}^{2}$ (Tomascik et al, 1997 dalam Moosa 2001; Rompas 2001). Berdasarkan hasil pemantauan Puslitbang Lembaga Oceanologi Indonesia pada 556 lokasi sampai bulan Januari 2003, hanya tinggal $6.83 \%$ terumbu karang Indonesia yang masih dikatagorikan sangat baik, 25.72\% baik,
$38.87 \%$ cukup dan $30.58 \%$ dalam kondisi buruk (Suharsono 2003).

Upaya rehabilitasi kawasan ekosistem terumbu karang di Indonesia perlu segera dilakukan karena saat ini kondisinya sudah sangat menurun. Bila pemulihannya dilakukan secara alami memerlukan waktu yang relatif lama sehingga diperlukan upaya percepatan pertumbuhan dengan rekayasa teknologi tertentu seperti:

a) Teknologi terumbu buatan (artificial reef) merupakan suatu struktur bangunan yang ditenggelamkan di dasar laut dan diharapkan dapat berfungsi menyerupai terumbu karang alami yakni sebagai tempat berlindung, mencari makan, memijah dan berkembang biak bagi biota yang berasosiasi di dalamnya.

b) Teknologi transplantasi karang (coral transplantation) adalah metode penanaman dan penumbuhan suatu koloni karang baru dengan metode fragmentasi untuk ditempatkan pada daerah yang mengalami kerusakan.

Teknik pertama (a) telah dilakukan di Indonesia dan hasilnya sangat memuaskan, teknik kedua juga sudah diterapkan di beberapa provinsi di Indonesia.

Negara-negara maju seperti Australia yang memiliki kepedulian tinggi terhadap kelangsungan 
hidup terumbu karang, telah menerapkan teknologi transplantasi karang untuk tujuan wisata bahari dan untuk rehabilitasi ekosistem terumbu karang. Di Teluk Kanehoe Hawai, transplantasi karang telah dilakukan untuk menghadirkan kembali dua jenis ekosistem terumbu karang yang telah mati akibat pembuangan kotoran melalui air (Maragos 1974 cit Harriot \& Fisk 1988), Guam menggunakan teknik transplantasi untuk menggantikan karang mati akibat aliran air panas pembangkit tenaga listrik, Florida menggunakan teknik ini untuk mempercepat dan memperbanyak tutupan karang, Taman Laut Great Barrier Reef, menggunakan teknik transplantasi untuk mempercepat regenerasi ekosistem terumbu karang yang telah rusak akibat Acanthaster plancii (Harriot \& Fisk 1988), Filipina menggunakan teknik ini untuk memperbaiki ekosistem terumbu karang yang mengalami kerusakan akibat penangkapan ikan yang memakai bahan peledak (Auberson 1982) dan Singapura menggunakan teknik transplantasi untuk menyimpan spesies yang habitatnya direklamasi.

Begitu kompleks dan pentingnya keberadaan terumbu karang, maka perlu adanya upaya rehabilitasi dan pengelolaan untuk menjaga dan memelihara ekosistem tersebut dan habitat yang berasosiasi di sekitarnya, agar tetap dalam kondisi yang baik. Salah satu upaya rehabilitasi yang sedang dikembangkan adalah fragmentasi karang. Dengan membuat lingkungan yang cocok bagi kehidupan karang dan bagaimana mengendalikan bentuk karang hidup (life form) dengan memanfaatkan sifat pertumbuhan karang. sehingga salah satu kegiatan yang sudah dilakukan adalah menfragmentasi 2 jenis karang batu (Cynarina lacrimalis dan Caulastrea furcata) menjadi beberapa bagian dalam kondisi terkontrol (kolam), dengan tujuan selain melestarikan jenis karang yang sudah langka (Cynarina lacrimalis) juga dapat menyediakan bibit karang untuk tujuan konservasi tanpa harus merusak lagi karang yang ada di alam bebas.

\section{BAHAN DAN METODE}

Penelitian dilaksanakan di Laboratorium Pusat Riset Perikanan Tangkap yang terletak di jalan Pasir Putih Ancol Jakarta Utara
Persiapan Bak Pemeliharaan. Bak pemeliharaan yang digunakan terbuat dari semen dengan ukuran $8 \mathrm{~m} \times 1,5 \mathrm{~m} \times 1 \mathrm{~m}$ dengan ketinggian air $90 \mathrm{~cm}$. Bak tersebut dilengkapi dengan penyaring biofiltrasi masing-masing berukuran $1 \mathrm{~m} \times 0,7 \mathrm{~m} \times 1$ $\mathrm{m}$ yang diberi berbagai lapisan dari bawah ke atas terdiri dari batu gravel besar, jaring, arang aktif dan gravel kecil. Proses penyaringan air laut dilakukan dengan memompakan air laut ke dalam bak penyaringan setelah itu baru dipompakan kembali ke bak pemeliharaan atau lebih dikenal dengan sistem resirkulasi.

Pemberian Pakan Tambahan. Untuk menunjang pertumbuhan karang maka karang diberi makan tambahan berupa plankton dari jenis copepod dan nano chloropsis. Pemberian pakan dilakukan dua kali sehari yaitu pada pagi hari dan sore hari sebanyak 5 liter air hasil kultur tanpa menghitung jumlah kepadatan plankton tersebut, hal ini dilakukan karena $90 \%$ pakan karang berasal dari symbiosisnya sendiri yaitu zooxanthellae. Jadi pemberian plankton hanya sebagai pakan tambahan dan manipulasi lingkungan agar air laut yang dialirkan ke kolam juga mengandung plankton.

Metode Pengambilan Karang. Sampel karang sebagai hewan uji penelitian jenis Caulastrea furcata diambil di Pulau Pari Kepulauan Seribu dengan menggunakan alat scuba pada kedalaman 3 meter, pemotongan dilakukan dengan gunting dan pahat sedangkan jenis Cynarina lacrimalis didapatkan dari eksportir karang hias.

Aklimatisasi dan Fragmentasi. Sebelum difragmentasi karang terlebih dahulu diadaptasikan selama dua minggu dan apabila dalam jangka dua minggu karang kelihatan sehat maka dilanjutkan dengan fragmentasi. Karang jenis Caulastrea furcata difragmentasi dengan menggunakan gunting pemotong dengan cara memotong karang tersebut pada bagian pangkalnya menjadi beberapa bagian (1 polip, 2 polip, 3 polip dan 4 polip) (Gambar 1). Karang Jenis Cynarina lacrimalis mempunyai bentuk satu polip dan soliter maka pemotongan dilakukan dengan membelah karang tersebut menjadi beberapa bagian ( 1 bagian, 2 bagian, 3 bagian dan 4 bagian). Masing-masing perlakuan tersebut diulang sebanyak tiga kali dan untuk melihat keberhasilan teknologi ini maka karang diamati setiap hari dan diukur 
pertumbuhan dan kelangsungan hidupnya setiap 20 hari sekali. Data yang telah dikumpulkan dianalisis dengan Rancangan Acak Lengkap menggunakan SPSS for Windows.

\section{HASIL DAN PEMBAHASAN}

Kualitas Air. Kualitas air sangat berperan untuk kelangsungan hidup karang. Parameter kualitas air di kolam harus sama dengan kualitas air di laut tempat hewan uji diambil. Pada Tabel 1 dapat dilihat perbandingan antara kualitas air di kolam pemeliharaan dan laut.

Ketahanan Hidup Caulastrea furcata. Secara umum karang Caulastrea furcata (trompet coral) tersebut memiliki ketahanan hidup yang tinggi. Ketahanan hidup tertinggi terjadi pada perlakuan T1 (1 polip) yaitu $100 \%$ diikuti perlakuan T3 $(88,9 \%)$,
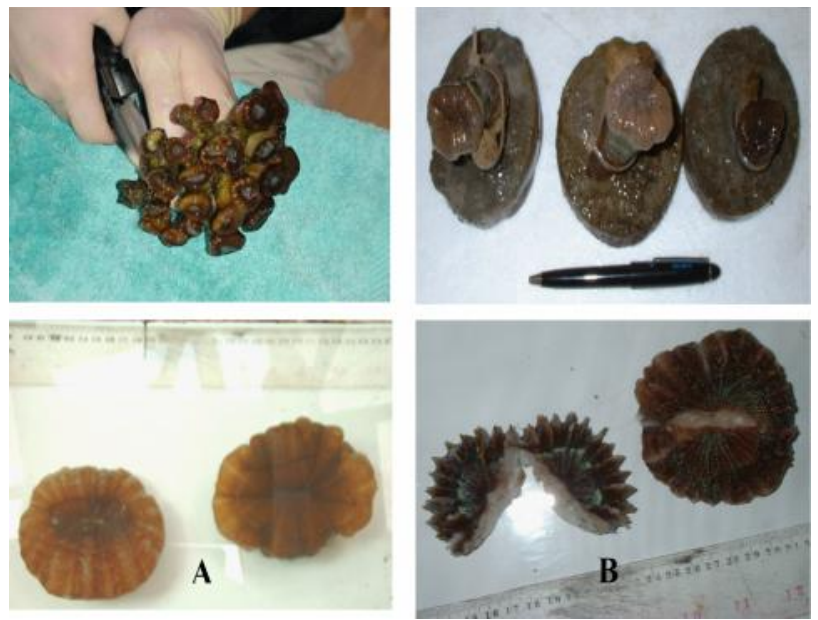

Gambar 1. Karang jenis Caulastrea furcata (atas) dan Cynarina lacrimalis. sebelum difragmentasi (A), Setelah diberi perlakuan dengan fragmentasi menjadi satu polip dan dua bagian (B) perlakuan T2 $(66,7 \%)$ dan terendah pada perlakuan T4 yaitu 58,34\% (Tabel 2).

Rendahnya ketahanan hidup dari masing-masing perlakuan selain $\mathrm{T} 1$ adalah diduga karena algae yang tumbuh subur hingga menutupi permukaan polip karang sampai mati, ataupun karena stress yang terjadi akibat lingkungan yang tidak persis sama dengan lingkungan aslinya. Hubbard (1997), menyatakan bahwa kesuburan perairan yang ditandai dengan banyaknya algae (turf algae) dapat menyebabkan kompetisi ruang bagi karang. Kemudian Brown \& Howard (1985), menyatakan bahwa stress pada terumbu karang dapat diprediksi dengan mengamati respon-respon terumbu karang terhadap faktor penyebab stres.

Pertumbuhan Karang Jenis Caulastrea furcata. Pertumbuhan Panjang. Pertumbuhan panjang mutlak karang jenis Caulastrea furcata. yang diamati selama 23 minggu (160 hari) didapatkan pertambahan panjang mutlak polip karang diperoleh rata-rata pertumbuhan per bulan adalah $1,64 \mathrm{~mm} /$ bln untuk T1, kemudian T2 (1,55mm/bln, T3 $(1,42 \mathrm{~mm} /$ bln) dan pertumbuhan panjang polip terendah terjadi pada T4 yaitu 1,08 mm/bln. Dari Gambar 2 dapat dilihat bahwa pertumbuhan panjang mutlak polip karang Caulastrea furcata tertinggi adalah pada perlakuan pemotongan menjadi 1 polip (T1) yaitu 8,77 $\mathrm{mm}$ dan terendah pada perlakuan pemotongan menjadi 4 polip (T4) yaitu $5,77 \mathrm{~mm}$.

Berdasarkan analisis sidik ragam tidak terdapat pengaruh nyata $(P>0,05)$ dengan adanya perbedaan pemotongan menjadi 1, 2, 3 dan 4 polip disebabkan karena pada masing - masing perlakuan T1, T2, T3

Tabel 1. Kualitas air media pemeliharaan karang.

\begin{tabular}{|c|c|c|c|c|c|c|c|c|}
\hline \multirow[b]{2}{*}{ No. Sample } & \multicolumn{8}{|c|}{ Parameter } \\
\hline & $\mathrm{pH}$ & $\begin{array}{c}\text { Salinitas } \\
\%\end{array}$ & $\begin{array}{l}\text { Suhu } \\
{ }^{\circ} \mathrm{C}\end{array}$ & $\begin{array}{c}\mathrm{O}_{2} \\
(\mathrm{ml} / \mathrm{l})\end{array}$ & $\begin{array}{c}\text { Fosfat } \\
(\mu \mathrm{g} \mathrm{A} / \mathrm{l})\end{array}$ & $\begin{array}{l}\text { Nitrat } \\
(\mu \mathrm{g} \mathrm{A} / \mathrm{l})\end{array}$ & $\begin{array}{c}\text { Nitrit } \\
(\mu \mathrm{g} A / \mathrm{l})\end{array}$ & $\begin{array}{c}\text { Ammonia } \\
(\mu \mathrm{g} \mathrm{A} / \mathrm{l})\end{array}$ \\
\hline Kolam & 8.08 & $32-33$ & $26-27$ & 5.74 & 0.169 & 0.3448 & 0.35 & 0.218 \\
\hline Laut Asal & 7.5 & 33 & $29-30$ & 5.91 & $0.015-0.018$ & 0.003 & 0.048 & 0.005 \\
\hline
\end{tabular}

Tabel 2. Ketahanan hidup karang Caulastrea sp. selama pengamatan 160 hari

Ketahanan hidup (\%)

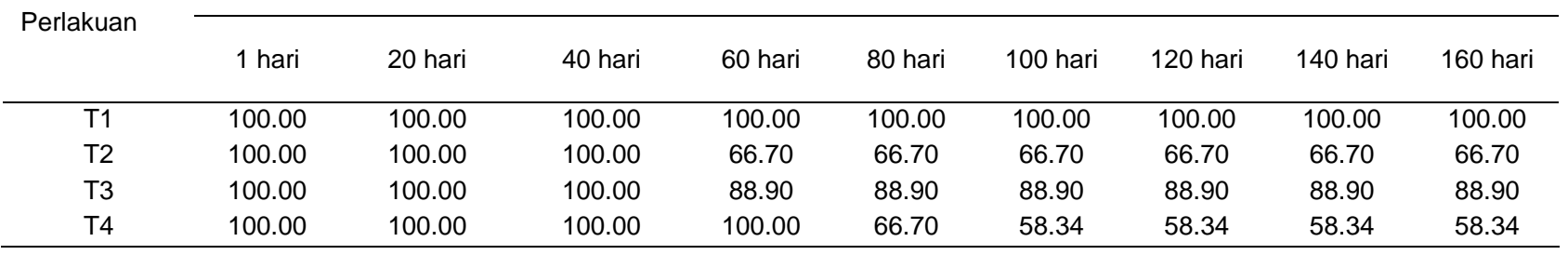




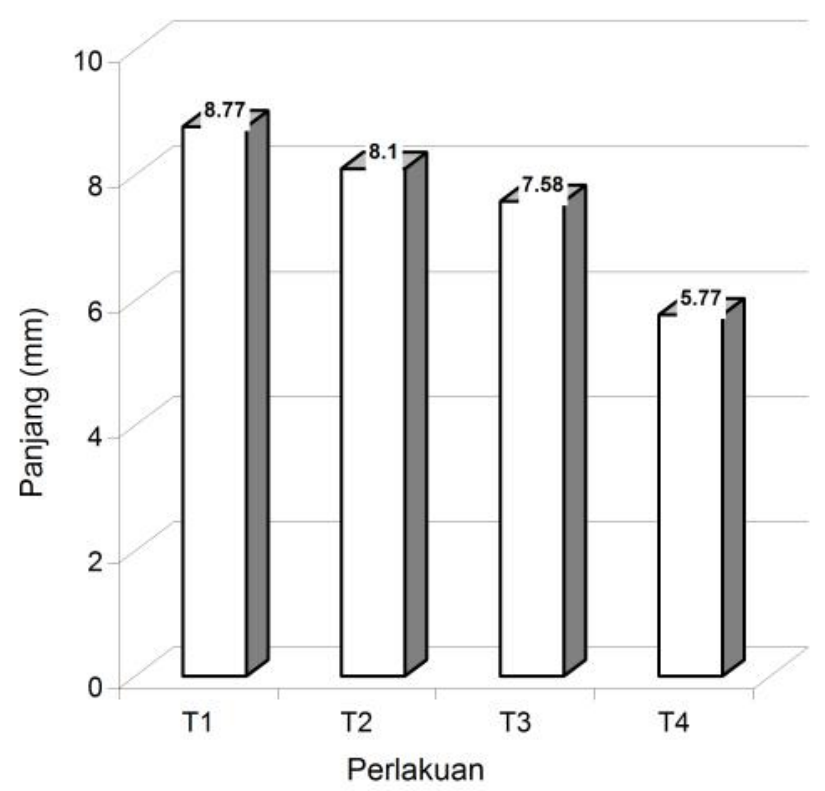

Gambar 2. Pertumbuhan panjang mutlak karang Caulastrea sp.

dan T4 pertumbuhannya relatif sama atau pertumbuhannya lambat sehingga tidak berpengaruh terhadap pertumbuhan panjang mutlak karang Caulastrea furcata. Hal ini sesuai pendapat Veron (1986) bahwa pada karang Caulastrea sp. memiliki pertumbuhan yang lambat sehingga memerlukan waktu yang cukup lama untuk tumbuh. Suharsono (1984), menyatakan bahwa karang yang mempunyai polip besar memiliki pertumbuhan lebih lambat dibanding karang yang mempunyai polip kecil.

Laju pertumbuhan panjang polip pada perlakuan pemotongan satu polip lebih baik dibandingkan dengan perlakuan lainnya hal ini disebabkan ruang yang dimiliki oleh polip karang jenis ini untuk dapat tumbuh ke samping lebih leluasa dan tidak adanya persaingan dalam memperoleh makanan karena hanya terdiri dari satu polip. Hasil penelitian ini menunjukkan perlakuan pemotongan satu polip dapat berkembang menjadi dua polip pada umur 11 minggu setelah fragmentasi dilakukan.

Cahaya yang ada di sekitar kolam mendukung untuk pertumbuhan karang yaitu 450-490 f.c. Hal ini sesuai dengan pendapat Kanwisher dan Wainwright dalam Supriharyono (2000) yaitu titik kompensasi binatang karang terhadap cahaya adalah 200-700 f.c. Pendapat ini juga diperkuat oleh Verron (1986) dan Nybakken (1992) bahwa cahaya adalah salah satu faktor penting untuk pertumbuhan karang karena karang $90 \%$ makanannya disalurkan oleh zooxanthellae yang membutuhkan cahaya untuk

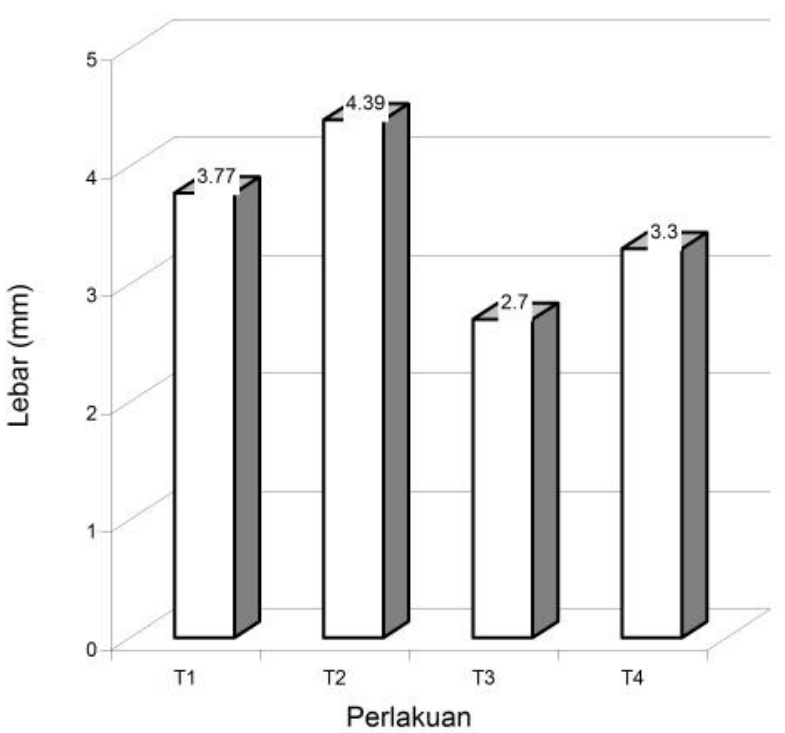

Gambar 3. Pertumbuhan lebar mutlak karang Caulastrea sp.

kelangsungan hidupnya dalam menjalani proses fotosintesis

Lingkungan kolam percobaan masih belum sempurna sebagaimana habitat aslinya diduga dapat menyebabkan pertumbuhan karang menjadi lambat dibanding pertumbuhan pada habitat aslinya, terutama menyangkut faktor kedalaman dan sirkulasi air kolam serta interaksi dengan spesies lain yang ada pada ekosistem terumbu karang.

Pertumbuhan Lebar. Pertumbuhan lebar mutlak polip karang jenis Caulastrea furcata didapatkan data laju pertumbuhan lebar tertinggi terjadi pada T2 yaitu 4,39 $\mathrm{mm}$ dan terendah terjadi pada perlakuan T3 yaitu $2,7 \mathrm{~mm}$. Sehingga rata-rata pertumbuhan lebar polip karang perbulan setiap polip adalah pada $\mathrm{T} 1(0,71$ $\mathrm{mm} / \mathrm{bln})$, T2 (0,82 mm/bln), T3 (0,51 mm/bln) dan T4 $(0,62 \mathrm{~mm} / \mathrm{bln})$.

Berdasarkan analisis sidik ragam tidak terdapat pengaruh yang nyata $(P>0,05)$ dengan adanya perbedaan pemotongan menjadi 1, 2, 3 dan 4 polip. Hal ini disebabkan karena pada masing-masing perlakuan $\mathrm{T} 1, \mathrm{~T} 2, \mathrm{~T} 3$, dan $\mathrm{T} 4$ pertumbuhannya relatif sama atau pertumbuhannya yang lambat sehingga tidak berpengaruh terhadap pertumbuhan lebar mutlak karang Caulastrea furcata.

Pertumbuhan Tinggi. Pertumbuhan tinggi mutlak karang jenis Caulastrea furcata yang diamati selama 23 minggu (160 hari) menunjukkan laju yang berbeda pada setiap perlakuan. Perlakuan T2 dan T4 yaitu masing-masing 6,64 $\mathrm{mm}$ kemudian diikuti oleh 


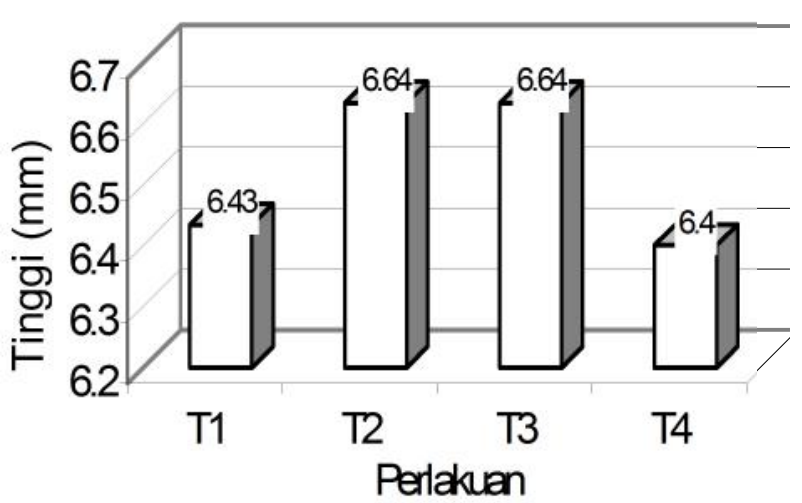

Gambar 4. Pertumbuhan tinggi mutlak karang Caulastrea furcata

Tabel 3. Ketahanan hidup karang Cynarina lacrimalis selama 80 hari

\begin{tabular}{cccccc}
\hline \multirow{2}{*}{ Perlakuan } & \multicolumn{5}{c}{ Ketahanan hidup (\%) } \\
\cline { 2 - 6 } & 1 hari & 20 hari & 40 hari & 60 hari & 80 hari \\
\hline T1 & 100 & 100 & 100 & 100 & 100 \\
T2 & 100 & 100 & 83.3 & 66.7 & 66.7 \\
T3 & 100 & 77.7 & 77.7 & 66.7 & 66.7 \\
T4 & 100 & 91.67 & 75 & 75 & 58 \\
\hline
\end{tabular}

T1 $(6,43 \mathrm{~mm})$ dan terendah pada T4 yaitu $6,4 \mathrm{~mm}$ (Gambar 4).

Tingginya laju pertumbuhan pada T2 dan T3 adalah karena dengan jumlah polip dua dan tiga buah lebih bisa memanfaatkan makanan secara optimal dibanding dengan satu polip. Sedangkan pada perlakuan empat polip (T4) ada beberapa ulangan yang mengalami kematian akibat diserang oleh algae, sehingga jumlah zooxanthellae yang ada di dalamnya berkurang dan dapat menghambat proses kalsifikasi akibatnya pertumbuhan karang menjadi terganggu.

Berdasarkan analisis sidik ragam menunjukkan bahwa adanya perlakuan pemotongan jumlah polip yang berbeda tidak berpengaruh nyata terhadap pertumbuhan tinggi mutlak karang jenis Caulastrea furcata yaitu rata-rata hanya 6,4-6,64 mm. Kecepatan kalsifikasi ini tidak sama untuk setiap spesies. Spesies tertentu sangat cepat yaitu bisa melebihi $2 \mathrm{~cm} /$ bulan (umumnya branching corals), namun ada pula spesies karang (umumnya massive corals) yang tumbuhnya sangat lambat, yaitu hanya kurang dari $1 \mathrm{~cm} / \mathrm{thn}$ (Goreau \& Goreau 1959 dalam Supriharyono (2000)).

Ketahanan Hidup Karang Cynarina lacrimalis. Secara umum karang Cynarina lacrimalis memiliki ketahanan hidup yang tinggi karena dia merupakan

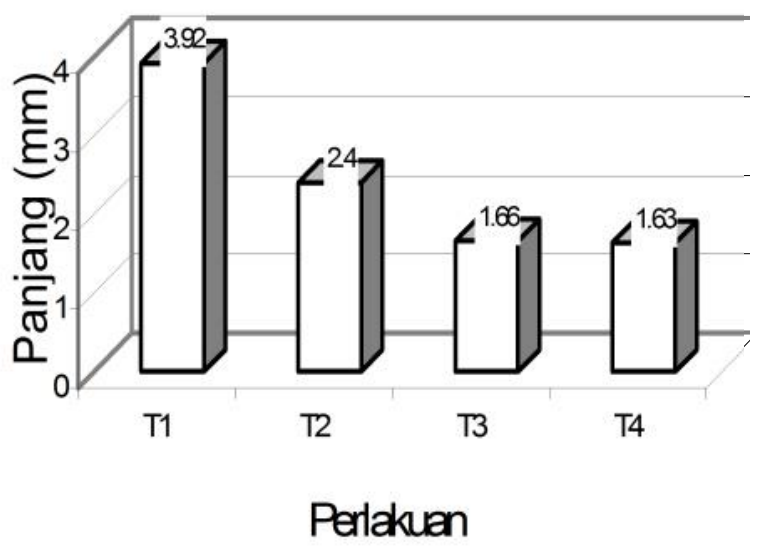

Gambar 5. Pertumbuhan panjang mutlak karang Caulastrea lacrimalis

karang yang soliter sehingga tidak terjadi kompetisi ruang dalam mempertahankan diri. Ketahanan hidup tertinggi terjadi pada perlakuan $\mathrm{T} 1$ yaitu $100 \%$ diikuti perlakuan T2 dan T3 yaitu masing-masing (66,7\%) dan terendah pada perlakuan T4 yaitu $58,0 \%$ (Tabel $3)$.

Ketahanan hidup menurun diduga karena merupakan respon dari karang tersebut yang telah dipotong sehingga mengalami strees dan tidak sanggup mempertahankan hidupnya. Bak dan Criens (1981), menyatakan bahwa ukuran fragmen karang sangat menentukan keberhasilan hidup, karena berhubungan dengan laju regenerasi dan kemampuan melepaskan diri dari tutupan sedimen. Menurut Harriot dan Fisk (1988), kegiatan transplantasi dapat dikatakan berhasil apabila jumlah karang yang hidup dari keseluruhan yang ditransplantasi lebih besar dari $50 \%$.

Dari hasil fragmentasi jenis karang jenis Cynarina lacrimalis yang dibagi menjadi 4 bagian sehingga sudah tidak utuh lagi, ternyata bagian-bagian tissu dari karang tersebut mampu bertahan hidup selama 80 hari, padahal tidak mendapatkan pasokan pakan secara normal (melalui mulut). Faktor utama penyebab kematian karang di kolam percobaan lebih disebabkan adanya expansi/blooming jenis algae tertentu yang mengganggu kehidupannya.

Pertumbuhan Karang Cynarina lacrimaris. Pertumbuhan Panjang. Pertumbuhan panjang mutlak karang jenis Cynarina sp. yang diamati selama 12 minggu (80 hari) diperoleh rata-rata pertumbuhan per bulan adalah $1,47 \mathrm{~mm} / \mathrm{bln}$ untuk $T 1$, kemudian T2 (0,90 mm/bln), T3 (0,62 mm/bln) dan pertumbuhan panjang polip terendah adalah pada $\mathrm{T} 4$ yaitu $0,61 \mathrm{~mm} /$ 
bln. Pada Gambar 5 dapat dilihat bahwa pertumbuhan panjang mutlak polip karang Cynarina lacrimalis tertinggi adalah pada perlakuan tanpa pemotongan (T1) yaitu $3,92 \mathrm{~mm}$ dan terendah pada perlakuan pemotongan menjadi 4 bagian (T4) yaitu 1,63 $\mathrm{mm}$.

Tingginya laju pertumbuhan panjang pada T1 karena pada perlakuan ini tidak dilakukan pemotongan sehingga karang berada dalam keadaan utuh. Makanan dan cahaya dapat diserap sepenuhnya oleh karang tersebut. Sedangkan pada perlakuan T2, T3 dan T4 ukuran karang sudah semakin kecil akibat fragmentasi dan mulut dari karang yang soliter inipun sudah bisa dikatakan tidak ada lagi sebagai akibat dari pemotongan. Semakin besar ukuran polip maka semakin besar kesempatan untuk memperoleh makanan bagi hewan karang dan cahaya bagi zooxanthellae sehingga apabila ukuran polip besar maka diduga jumlah zooxanthellae juga lebih banyak sehingga laju proses kalsifikasi pun akan lebih cepat terjadi pada karang yang mempunyai permukaan lebih luas dibanding yang mempunyai permukaan kecil. Hal ini sejalan dengan pendapat Franzisket (1969) dalam Nybakken (1992) memperlihatkan bahwa, jika karang tidak diberi makan tetapi tetap terkena cahaya, mereka akan bertambah beratnya dan ini hanya dapat terjadi jika zooxanthellae menyediakan makanan bagi mereka. Hawker dan Connel (1992), menyatakan bahwa polip bersimbiosis dengan alga bersel satu yaitu zooxanthellae yang hidup di dalam lapisan gastrodermis. Hewan karang dan zooxanthellae bersimbiosis secara mutualisme. Keuntungan

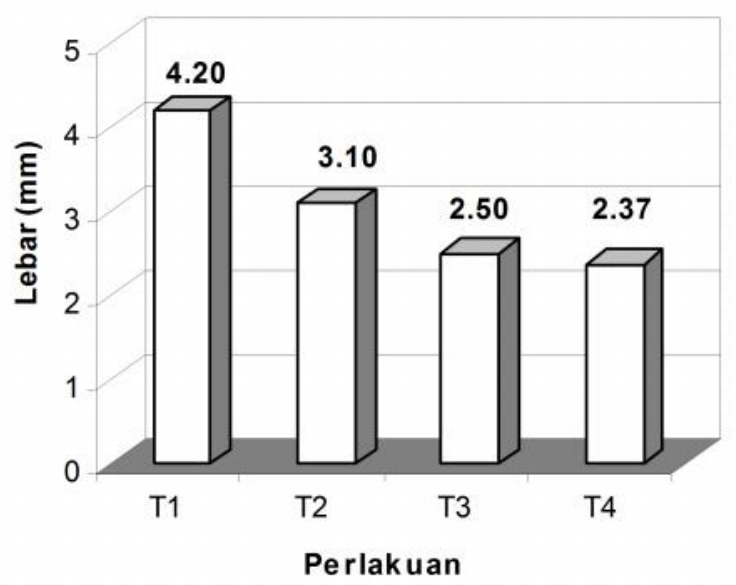

Gambar 6. Pertumbuhan lebar mutlak karang Cynarina lacrimalis hewan karang adalah diperolehnya tempat hidup dan perlindungan dari hewan pemangsa serta mendapat limpahan buangan dari metabolisme karang (protein dan karbohidrat) dan $\mathrm{CO}_{2}$ untuk proses fotosintesis. Sedangkan keuntungan hewan karang dari simbiosis ini adalah proses pembuangan dari bahan-bahan sisa menjadi efisien dan dapat menyerap langsung hasil fotosintesa zooxanthellae sebagai sumber makanannya.

Hasil percobaan menunjukkan mulut karang yang difragmentasi menjadi 2 bagian dan 3 bagian mulut dari karang Cynarina lacrimalis ini kembali utuh pada pemeliharaan hari ke 70 setelah fragmentasi dilakukan. Cahaya yang ada di sekitar kolam mendukung untuk pertumbuhan karang yaitu 450-490 f.c. Hal ini sesuai dengan pendapat Kanwisher dan Wainwright dalam Supriharyono (2000) yaitu titik kompensasi binatang karang terhadap cahaya adalah 200-700 f.c.

Pertumbuhan Lebar. Pertumbuhan lebar mutlak polip karang jenis Cynarina lacrimalis selama penelitian dapat dilihat Gambar 6, di mana laju pertumbuhan lebar tertinggi terjadi pada $\mathrm{T} 1$ yaitu 4,20 $\mathrm{mm}$ dan terendah terjadi pada perlakuan T4 yaitu 2,37 $\mathrm{mm}$. Sehingga rata-rata pertumbuhan lebar polip karang per bulan setiap polip adalah pada T1 $(1,57$ $\mathrm{mm} / \mathrm{bln})$, T2 (1,16 mm/bln), kemudian pada T3 $(0,93$ $\mathrm{mm} / \mathrm{bln})$ dan T4 (0,89 mm/bln).

Tingginya laju pertumbuhan lebar pada T1 sama halnya dengan pertumbuhan panjang mutlak yaitu pada perlakuan ini tidak dilakukan pemotongan sehingga karang berada dalam keadaan utuh.

Berdasarkan analisis sidik ragam maka didapatkan bahwa pemotongan karang Cynarina lacrimalis menjadi 2 bagian, 3 bagian dan 4 bagian memberikan pengaruh yang sangat nyata $(P<0,01)$. $\mathrm{Hal}$ ini disebabkan karena pada perlakuan T1 tidak dilakukan pemotongan sehingga mulut karang masih utuh sehingga tidak membutuhkan energi untuk pemulihan dan dapat menangkap makanan dengan leluasa serta penyinaran yang cukup membuat ada pada karang $\mathrm{T} 1$ dapat berfotosintesis dengan baik untuk menyuplai makanan ke hewan karang, 
sedangkan pada pemotongan menjadi 2 bagian (T2), tiga bagian (T3) dan empat bagian (T4) masingmasing telah kehilangan mulut, sehingga hanya mengandalkan hidup pada zooxanthellae yang bersimbiosis padanya. Hasil uji tukey menunjukkan bahwa terdapat perbedaan yang nyata antar perlakuan T1 dengan perlakuan T3 dan T4, sedangkan antara T1 dan T2 tidak terdapat perbedaan nyata, dan antara T2 dengan T3 dan T4 juga tidak terdapat perbedaan yang nyata karena masingmasing perlakuan pertumbuhannya lambat.

\section{KESIMPULAN}

Selama penelitian ditemukan bahwa perlakuan yang terbaik untuk jenis karang Caulastrea furcata adalah dengan fragmentasi 1 polip yaitu dengan panjang mutlak 8,77 mm sedangkan karang Cynarina lacrimalis pada perlakuan T1 yaitu tanpa pemotongan yaitu dengan panjang mutlak 3,92 $\mathrm{mm}$. Fragmentasi optimal dilakukan untuk jenis karang yang mempunyai polip banyak dengan menfragmen karang tersebut menjadi satu polip, sedangkan untuk karang yang soliter fragmentasi dengan membagi menjadi beberapa bagian juga dapat dilakukan tetapi pertumbuhannya akan sangat lambat bahkan dapat menyebabkan kematian.

\section{UCAPAN TERIMA KASIH}

Penulis mengucapkan terima kasih kepada DIKTI yang telah mendanai penelitian inimelalui Riset Unggulan Terpadu. Terima kasih juga kepada Pusat Riset Perikanan Tangkap Ancol Jakarta Utara yang telah memberikan fasilitas tempat penelitian.

\section{DAFTAR PUSTAKA}

Bak, R.P.M. \&. Criens, S.R. 1981. Survival after fragmentation of colonies of Madracis mirabilis, Acropora palmata and $A$. Cervicornis (Scleractinia) and The subsequent impact of coral desease. Manila: Proc. Of 4th Int. Coral Reef Sym. 2: .221227.

Brown, B.E. \& Howard, L.S. 1985. Assessing the effects of stress on reef corals. Pp: 1-63. Di dalam: Blaxter. J.H.S., The late Sir Frederick S. Russel and Sir Maurice Yonge (Editors). Advances in Marine Biology. Academic Press. Vol 22.

Harriot V.J. \& Fisk, D.A. 1988. Coral transplantation as reef management option. Australia: Proc. $6^{\text {th }}$. Int. Coral Reef Symp. 2: 375-378

Hubbard, D.K. 1997. Reefs as dynamic systems. Pp: 43-67.Di dalam: Birkeland, C. (Editor). Life and death of coral reefs. University of Guam. International Thomson Publising.

Moosa, M. \& Kasim. 2001. Terumbu karang Indonesia dan permasalahan yang dihadapi. Makalah Seminar Nasional Terumbu Karang Universitas Negeri Jakarta.

Nybakken, J. W. 1992. Bologi Laut. Suatu pendekatan ekologis. Terjemahan oleh Eidman, M., Bengen, D.G., Koesoebiono, M., Hutomo dan Sukristijono, PT.

Rompas \& Rizald Max. 2001. Kerusakan ekosistem terumbu karang dan dampaknya terhadap pengelolaan sumberdaya laut. Makalah Seminar Nasional Universitas Negeri Jakarta.

Suharsono. 1984. Pertumbuhan Karang. Oseana IX. Jakarta: Pusat Penelitian Biologi Laut. LON-LIPI 2 : 41-48

Suharsono. 2003. Kondisi terumbu karang di Indonesia. http:// www.coremap.or.id/tentang karang (10 Juli 2003)

Supriharyono. 2000. Pengelolaan Ekosistem Terumbu Karang. Jakarta: Penerbit Djambatan. hlm 118.

Veron, J.E.N. 1986. Coral of Australia and The Indo-Pasific. August. Roberson. Publish. 644p. 